\title{
Foliar Urea Application in the Fall Affects Both Nitrogen and Carbon Storage in Young 'Concord' Grapevines Grown under a Wide Range of Nitrogen Supply
}

\author{
Guohai Xia ${ }^{1}$ and Lailiang Cheng ${ }^{2}$ \\ Department of Horticulture, Cornell University, Ithaca, NY 14853 \\ AdDitional INDEX wORDs. $\mathrm{C}: \mathrm{N}$ ratio, free amino acids, nitrogen fertigation, proteins, total nonstructural carbohydrates, \\ Vitis labruscana
}

\begin{abstract}
Aвstract. One-year-old 'Concord' grapevines (Vitis labruscana Bailey) were fertigated with 0, 5, 10, 15, or $20 \mathrm{~mm} \mathbf{N}$ in a modified Hoagland's solution for 8 weeks during summer. Half of the vines fertigated at each $\mathbf{N}$ concentration were sprayed with $3 \%$ foliar urea twice in late September while the rest served as controls. Four vines from each treatment combination were destructively sampled during dormancy to determine the levels and forms of $\mathrm{N}$ and carbohydrates. Nitrogen fertigation during the summer did not significantly alter vine $\mathrm{N}$ concentration whereas foliar urea application in the fall significantly increased vine $\mathbf{N}$ concentration. In response to foliar urea application, concentrations of both free amino acid- $\mathrm{N}$ and protein- $\mathrm{N}$ increased, but the ratio of protein- $\mathrm{N}$ to free amino acid- $\mathrm{N}$ decreased. Arginine was the most abundant amino acid in free amino acids and proteins, and its concentration was linearly correlated with vine $\mathbf{N}$ concentration. Concentrations of total nonstructural carbohydrates (TNC) decreased slightly in response to $\mathrm{N}$ supply from fertigation. Foliar urea application in the fall significantly decreased TNC concentration at each $\mathbf{N}$ fertigation level. Starch, glucose, and fructose decreased in response to foliar urea applications, but sucrose concentration remained unaffected. Approximately $60 \%$ of the carbon decrease in TNC caused by foliar urea application was recovered in proteins and free amino acids. We conclude that free amino acids account for a larger proportion of the $\mathrm{N}$ in vines sprayed with foliar urea compared with the unsprayed vines, but proteins remain as the main form of $\mathrm{N}$ storage. In response to foliar urea application, part of the carbon from TNC is incorporated into proteins and free amino acids, leading to a decrease in the carbon stored in TNC and an increase in the carbon stored in proteins and free amino acids.
\end{abstract}

The initial growth and development of deciduous fruit crops, including grapevines (Vitis spp.), are supported by remobilization of nutrients that are stored in perennial tissues from the previous growing season (Oliveira and Priestley, 1988; Wermelinger, 1991; Williams, 1991). Among them, nonstructural carbohydrates (TNC), including both starch and soluble sugars, make up the bulk part of the total reserves in a dormant vine. Total $\mathrm{N}$ in the form of proteins and free amino acids typically accounts for less than $2 \%$ of the dry matter of a dormant vine, of which only the proportion that can be remobilized the next spring is reserve $\mathrm{N}$. On a seasonal basis, both $\mathrm{N}$ and TNC concentrations in storage tissues (cane, trunk, and roots) of grapevines decrease rapidly when initial growth occurs in the spring (Bates et al., 2002; Löhnertz, 1991; Schaller et al., 1989). They remain at a low level during active shoot growth and fruit cell division. Although replenishment of both reserves begins earlier, the rapid accumulation does not take place until late in the season when other sinks slow down or stop their growth.

The effect of soil $\mathrm{N}$ application on vine growth, nitrogen uptake, partitioning, and storage has been examined in both potted

Received for publication 2 Mar. 2004. Accepted for publication 4 May 2004. This work was supported in part by USDA Viticulture Consortium Program and New York Wine/Grape Foundation. The authors thank Drs. Anil Ranwala and Bill Miller for help with carbohydrate analysis, Dr. Fengwang Ma for amino acid analysis, Dr. Kuo-Tan Li and Mr. Richard Raba for assistance with plant materials, and Drs. Marvin Pritts and Stanly Howell for critical reading of the manuscript.

1Permanent address: Department of Horticulture, Henan Agricultural University, Zhengzhou 450001, P.R. China.

${ }^{2}$ To whom reprint requests should be addressed: fax: 607-255-4355; e-mail: LC89@Cornell.edu and field-grown grapevines (Conradie, 1991; 1992; Hanson and Howell, 1995; Kliewer and Cook, 1971; Löhnertz, 1988, 1991; Williams, 1991). However, it is not known whether vine reserve carbohydrate status is also altered by soil $\mathrm{N}$ supply. In dormant, young apple (Malus $\times$ domestica Borkh.) trees, TNC concentrations decreased in response to an increase in soil $\mathrm{N}$ supply during summer (Cheng and Fuchigami, 2002). Considering that $\mathrm{N}$ affects both the source capacity to assimilate carbon and the sink activity to utilize assimilated carbon in grapevines (Chen and Cheng, 2003), it is expected that reserve carbohydrate status may respond to soil $\mathrm{N}$ supply. On the other hand, grapevines have more vigorous vegetative growth than apple trees, which may divert the assimilated $\mathrm{N}$ and carbon from partitioning into storage sinks to building vegetative structures. As a result, $\mathrm{N}$ and TNC concentrations may not respond dramatically to a wide range of $\mathrm{N}$ supply when applied during active shoot growth.

In addition to root uptake of $\mathrm{N}$ from soil, leaves can absorb foliar-applied urea in the fall and the nitrogen derived from foliar urea can be translocated back to storage tissues. Foliar N application in the fall significantly increased $\mathrm{N}$ content in dormant tissues of apple (Oland, 1963; Shim et al., 1972), pear (Pyrus communis L.) (Sanchez et al., 1990), peach and nectarine (Prunus persica L.) (Rosecrance et al., 1998; Tagliavini et al., 1998), and almond [Prunus dulcis (Mill) D.A. Webb] (Bi et al., 2003) trees. The effect of fall foliar $\mathrm{N}$ application on the reserve $\mathrm{N}$ level of apple trees was dependent on tree $\mathrm{N}$ status (Cheng et al., 2002). The increase in tree $\mathrm{N}$ concentration by foliar urea spray caused a decrease in TNC concentration (Cheng and Fuchigami, 2002). Recently, it was shown that a large proportion of the decrease of carbon in carbohydrates caused by foliar urea application was 
recovered in proteins and free amino acids (Cheng et al., 2004a). How grapevines respond to foliar $\mathrm{N}$ application in the fall is not known. If vine $\mathrm{N}$ and TNC concentrations do not respond dramatically to soil $\mathrm{N}$ supply when applied during active shoot growth due to increased structural growth, then foliar N application in the fall after shoots have stopped their growth may be more effective in altering vine $\mathrm{N}$ and carbohydrate status. The objectives of this study were to determine effects of $\mathrm{N}$ fertigation during active vine growth in summer and foliar urea application in the fall on levels and forms of $\mathrm{N}$ and carbon storage in young 'Concord' grapevines.

\section{Materials and Methods}

Plant culture and nitrogen treatments. One-year-old, own-rooted 'Concord' grapevines were grown in sand culture in 18 -L containers. Each vine was pruned to two nodes before budbreak. Plants were grown outdoors at Cornell Orchards in Ithaca, N.Y. (lat. $42^{\circ} 26^{\prime} \mathrm{N}$, long. $76^{\circ} 29^{\prime} \mathrm{W}$ ). At budbreak, extra shoots were removed and only two vegetative shoots were allowed to grow on each vine. Beginning from the second week after budbreak, each plant was supplied once a week with $500 \mathrm{~mL}$ of $10 \mathrm{~mm} \mathrm{~N}$, using Peters $20 \mathrm{~N}-4.4 \mathrm{P}-16.6 \mathrm{~K}$ water-soluble fertilizer with micronutrients (Scotts-Sierra Horticultural Products, Marysville, Ohio). Starting from 22 June 2001, when new shoots were approximately $35 \mathrm{~cm}$ long, uniform plants were selected and randomly assigned to one of the following five $\mathrm{N}$ treatments. Each plant was supplied twice weekly with $500 \mathrm{~mL}$ of a modified Hoagland's solution at an $\mathrm{N}$ concentration of $0,5,10,15$, or 20 $\mathrm{mm}$ (from $\mathrm{NH}_{4} \mathrm{NO}_{3}$ ) (Cheng and Fuchigami, 2000) for 8 weeks until 17 Aug. No additional $\mathrm{N}$ or other nutrients was provided to the roots for the rest of the growing season. There were four replications at each $\mathrm{N}$ fertigation treatment with six vines each in a completely randomized design. All plants had stopped their terminal growth by 15 Sept. Half of the vines (12) at each N fertigation treatment were sprayed with $3 \%$ urea twice (20 and 29 Sept.) while the rest served as unsprayed controls. Foliar urea applications advanced leaf abscission by about 3 d. By 25 Oct., leaf abscission was completed across all the treatments and all the vines were moved to a cold room at 2 to $4{ }^{\circ} \mathrm{C}$ with pots for overwintering.

All the vines were pruned to 20 nodes on 26 Mar. 2002 when they were still dormant. Four vines from each of the 10 treatment combinations were destructively sampled right after pruning on the same day. Each vine was divided into 1-year-old cane, shank, and roots. All the samples were frozen at $-80{ }^{\circ} \mathrm{C}$, freeze-dried, then ground to pass 1-mm screen. A composite sample was made for each vine based on its dry matter distribution among different parts after pruning to determine the chemical composition of $\mathrm{N}$ and nonstructural carbohydrates.

Chemical analysis of Nitrogen and Carbohydrates. Tissue $\mathrm{N}$ concentration was determined by combustion analysis using a $\mathrm{C}: \mathrm{N}$ analyzer (Carlo Erba NC2500, Carlo-Erba/Fisons Instruments, Valencia, Calif.). Free amino acids were extracted from $300 \mathrm{mg}$ tissue sample with $7 \mathrm{~mL} 0.1 \mathrm{~m}$ sodium citrate buffer $(\mathrm{pH}$ 4.0) for $24 \mathrm{~h}$ at $4{ }^{\circ} \mathrm{C}$ (Oland, 1959). During this extraction period, samples were sonicated for $15 \mathrm{~min}$. The extract was centrifuged at $13,000 g_{\mathrm{n}}$ for $15 \mathrm{~min}$ and the supernatant was directly used in amino acid analysis after passing a $0.2-\mu \mathrm{m}$ filter. For total amino acids, $100 \mathrm{mg}$ tissue sample was hydrolyzed in $10 \mathrm{~mL} 6$ $\mathrm{m}$ hydrochloric acid at $110^{\circ} \mathrm{C}$ for $22 \mathrm{~h}$. After filtration, the total volume was brought to $25 \mathrm{~mL}$, an aliquot of which was taken to remove $\mathrm{HCl}$, then dissolved in a citrate buffer at $\mathrm{pH}$ of 2.2. After proper dilution, $50 \mu \mathrm{L}$ was injected into a Beckman 121 automatic amino acid analyzer, equipped with an FR-10 spherical cation exchange resin column (Beckman Instruments, Fullerton, Calif.). Individual amino acids were eluted at $54{ }^{\circ} \mathrm{C}$ with a citrate buffer at $\mathrm{pH} 3.28$ for $14 \mathrm{~min}$ first, then at $\mathrm{pH} 3.90$ for $10 \mathrm{~min}$, followed by elution at $\mathrm{pH} 5.26$ for $14 \mathrm{~min}$. The column was regenerated with $0.2 \mathrm{M} \mathrm{NaOH}$ for $5 \mathrm{~min}$, and then equilibrated with a citrate buffer at $\mathrm{pH}$ of 3.28 for 6 min before the next injection. Standard amino acids were added to tissue samples prior to extraction to determine the recovery of individual amino acids following the same extraction procedures above. On average, the recovery for free amino acids and total amino acids after protein hydrolysis was approximately $90 \%$ and $80 \%$, respectively.

For soluble carbohydrates, 50-mg composite samples, with xylitol added as an internal standard, were extracted three times at $80{ }^{\circ} \mathrm{C}$ with $80 \%$ ethanol ( $3 \mathrm{~mL}$ each, $30 \mathrm{~min}$ per extraction). Tissue suspensions were centrifuged at $4000 g_{\mathrm{n}}$ for $10 \mathrm{~min}$ after each extraction, and the supernatants were combined. The extract was passed through ion exchange columns consisting of $1 \mathrm{~mL}$ Amberlite IRA-67 (acetate form) (Sigma) and $1 \mathrm{~mL}$ Dowex 50W (hydrogen form) (Sigma) to remove charged material. The extract was then evaporated to dryness at $55^{\circ} \mathrm{C}$, and dissolved in 10 $\mathrm{mL}$ of water. After appropriate dilution, $25 \mu \mathrm{L}$ was injected into a Dionex DX-500 series chromatograph, equipped with a Carbopac PA-1 column, a pulsed amperometric detector, and a gold electrode (Dionex, Sunnyvale, Calif.). Soluble sugars (glucose, fructose, and sucrose) were eluted at a flow rate of $1.0 \mathrm{~mL} \cdot \mathrm{min}^{-1}$ with $200 \mathrm{~mm} \mathrm{NaOH}$ for $15 \mathrm{~min}$. The concentration of individual soluble carbohydrates was determined based on peak area and the calibration curve derived from the corresponding standard authentic sugar, and then adjustments were made based on the recovery of the internal standard for each sample. The tissue residue after soluble sugar extraction was dried, and then digested with amyloglucosidase at $55^{\circ} \mathrm{C}$ in a sodium acetate buffer $(\mathrm{pH}$ 4.5 ) overnight to convert starch to glucose. The concentration of glucose was quantified by using the Dionex. Total nonstructural carbohydrates were the sum of starch and soluble sugars.

Calculations and statistical analysis. Nitrogen in free amino acids or total amino acids after protein hydrolysis was the sum of $\mathrm{N}$ from individual amino acids adjusted for recovery. The difference between total $\mathrm{N}$ in amino acids after protein hydrolysis and that in free amino acids was considered as protein-N. Carbon in nonstructural carbohydrates was calculated as the sum of carbon in glucose, fructose, sucrose, and starch.

Analysis of variance (ANOVA) for a 5 ( $\mathrm{N}$ fertigation $) \times 2$ (foliar $\mathrm{N}$ ) factorial experiment with a completely randomized design was used for most variables measured in this study. Linear regression analysis was used for free arginine or total arginine in relation to tissue $\mathrm{N}$. All the statistical analyses were performed via SAS (SAS Institute, Cary, N.C.).

\section{Results}

DRY WEIGHT OF DORMANT VINES. Whole vine dry weight increased as $\mathrm{N}$ supply from fertigation increased (Fig. 1A). Foliar urea application in the fall did not significantly alter the dry weight of vines fertigated at each $\mathrm{N}$ concentration. Pruning to the same number of nodes slightly decreased the total dry weight of vines fertigated with high $\mathrm{N}$ concentrations (Fig. 1B).

CONCENTRATIONS OF NITROGEN AND TOTAL NONSTRUCTURAL CARBOHYDRATES. Nitrogen fertigation during the summer did not 

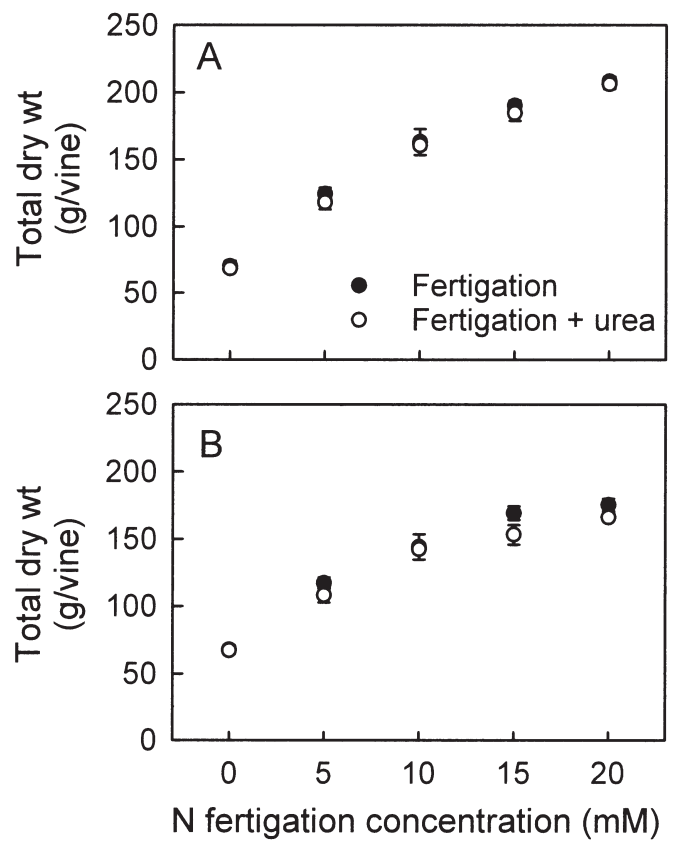

Fig. 1. Total dry weight of dormant 'Concord' grapevines before pruning (A) and after pruning (B) in response to $\mathrm{N}$ fertigation during summer and foliar urea application in the fall. Vines were destructively sampled on 26 Mar. 2002. Each point is a mean with standard error of four replicates. Each dependent variable was analyzed by analysis of variance for a 5 ( $\mathrm{N}$ fertigation) $\times 2$ (foliar urea) factorial experiment with a completely randomized design. For both dependent variables, $P$ values are $<0.0001$ for $\mathrm{N}$ fertigation, with no significant effect of foliar urea or interaction between the two $(P>0.05)$.

significantly alter $\mathrm{N}$ concentration of the dormant vines (Fig. 2A). Foliar urea application significantly increased vine $\mathrm{N}$ concentration across all five $\mathrm{N}$ fertigation treatments. TNC concentration decreased slightly in response to $\mathrm{N}$ supply from fertigation (Fig. 2B). Foliar urea application in the fall decreased TNC concentration at each $\mathrm{N}$ fertigation level, bringing the TNC concentration to a similar lower level across all the $\mathrm{N}$ fertigation treatments.

NITROGEN IN FREE AMINO ACIDS AND PROTEINS. Concentration of free amino acid-N remained relatively stable across all the $\mathrm{N}$ fertigation treatments (Fig. 3A). Foliar urea application in the fall increased the concentration of free amino acid-N at each $\mathrm{N}$ fertigation concentration. The $\mathrm{C}: \mathrm{N}$ ratio of free amino acids was approximately 2 , which was not altered by $\mathrm{N}$ fertigation or foliar urea application (Fig. 3B).

Arginine was the most abundant amino acid in the free amino acid pool. Free arginine concentration showed a similar response to $\mathrm{N}$ fertigation and foliar urea application as did free amino acid-N (data not shown). The ratio of free arginine- $\mathrm{N}$ to total $\mathrm{N}$ in free amino acids remained at 0.8 over the range of $\mathrm{N}$ fertigation concentrations (Fig. 3C). Foliar urea application in the fall did not alter this ratio.

The concentration of protein- $\mathrm{N}$ remained constant as $\mathrm{N}$ supplied from fertigation increased (Fig. 4A). Foliar urea application in the fall increased protein- $\mathrm{N}$ to a similar level over the range of $\mathrm{N}$ fertigation concentrations. The $\mathrm{C}: \mathrm{N}$ ratio of the proteins stayed at approximately 3.9 (Fig. 4B), whereas foliar urea application in the fall decreased the $\mathrm{C}: \mathrm{N}$ ratio of proteins to 3.5 across the range of $\mathrm{N}$ fertigation concentrations. Compared with free amino acids, proteins had a much higher $\mathrm{C}: \mathrm{N}$ ratio at each $\mathrm{N}$ level (Figs. 3B, 4B).
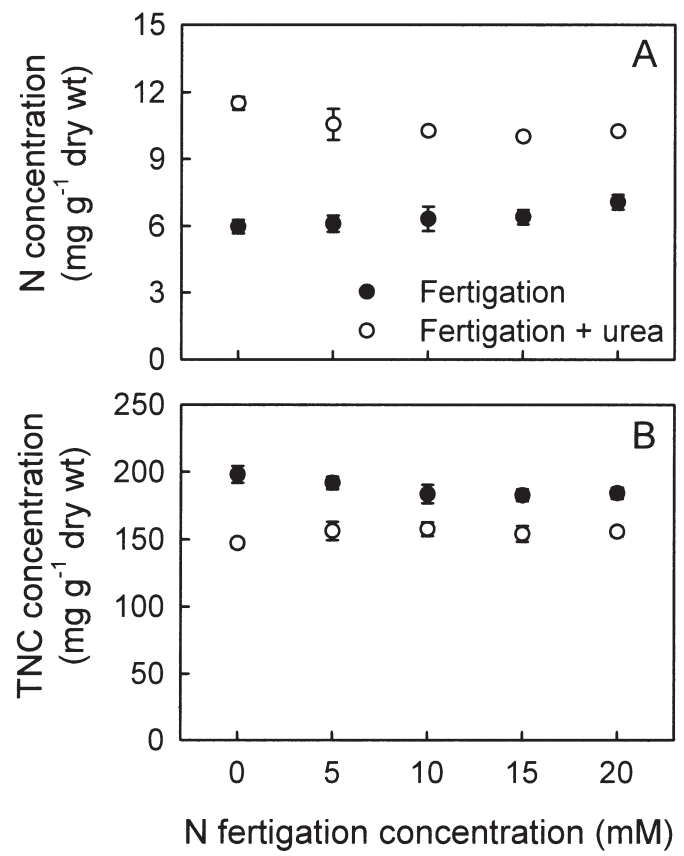

Fig. 2. Concentrations of $\mathrm{N}$ (A) and total nonstructural carbohydrates (TNC) (B) of dormant 'Concord' grapevines in response to $\mathrm{N}$ fertigation during summer and foliar urea application in the fall. Vines were destructively sampled on 26 Mar. 2002 after pruning to 20 nodes per vine. Each point is a mean with standard error of four replicates. Each dependent variable was analyzed by analysis of variance for a 5 ( $\mathrm{N}$ fertigation) $\times 2$ (foliar urea) factorial experiment with a completely randomized design. For both dependent variables, $P$ values are $<0.0001$ for foliar urea, with no significant effect of $\mathrm{N}$ fertigation or interaction between the two $(P>0.05)$.

The arginine set free by hydrolysis of proteins, responded to $\mathrm{N}$ fertigation and foliar urea application in a similar way as protein-N (data not shown). Arginine-N accounted for approximately $13.5 \%$ of protein- $\mathrm{N}$ regardless of $\mathrm{N}$ fertigation concentration (Fig. 4C). This percentage was increased to $27.5 \%$ by foliar urea application across the $\mathrm{N}$ fertigation concentrations.

Across all the $\mathrm{N}$ fertigation treatments, the sum of $\mathrm{N}$ in proteins and free amino acids remained fairly constant except for an increase at the highest $\mathrm{N}$ fertigation concentration (Fig. 5A). Foliar urea application increased the $\mathrm{N}$ in proteins and free amino acids to a similar level across the $\mathrm{N}$ fertigation treatments. The $\mathrm{C}: \mathrm{N}$ ratio of the sum of proteins and free amino acids showed a similar response to $\mathrm{N}$ supply as that of proteins alone, but with a smaller value at each level of $\mathrm{N}$ supply (Fig. 5B). The ratio of $\mathrm{N}$ in proteins to that of free amino acids decreased curvilinearly from 13.5 to 10.2 as $\mathrm{N}$ supply from fertigation increased from 0 to $20 \mathrm{~mm}$ (Fig. 5C). Foliar urea application in the fall decreased the $\mathrm{N}$ ratio to about 7.2 across $\mathrm{N}$ fertigation concentrations, with the decrease being larger in vines fertigated with low $\mathrm{N}$ concentrations than in those fertigated with high $\mathrm{N}$ concentrations.

Both free arginine- $\mathrm{N}$ and total arginine- $\mathrm{N}(\mathrm{N}$ from free arginine plus $\mathrm{N}$ from arginine in proteins) were linearly correlated with tissue $\mathrm{N}$ concentration across all treatments (Fig. 6).

InDIVIDUAL NONSTRUCTURAL CARBOHYDRATES. Glucose and fructose concentrations showed a similar response to $\mathrm{N}$ fertigation and foliar urea application (Fig. 7 A, B). Both remained relatively stable across the $\mathrm{N}$ fertigation treatments. Foliar urea application in the fall decreased both glucose and fructose concentrations at each $\mathrm{N}$ fertigation level. Sucrose concentration was not signifi- 

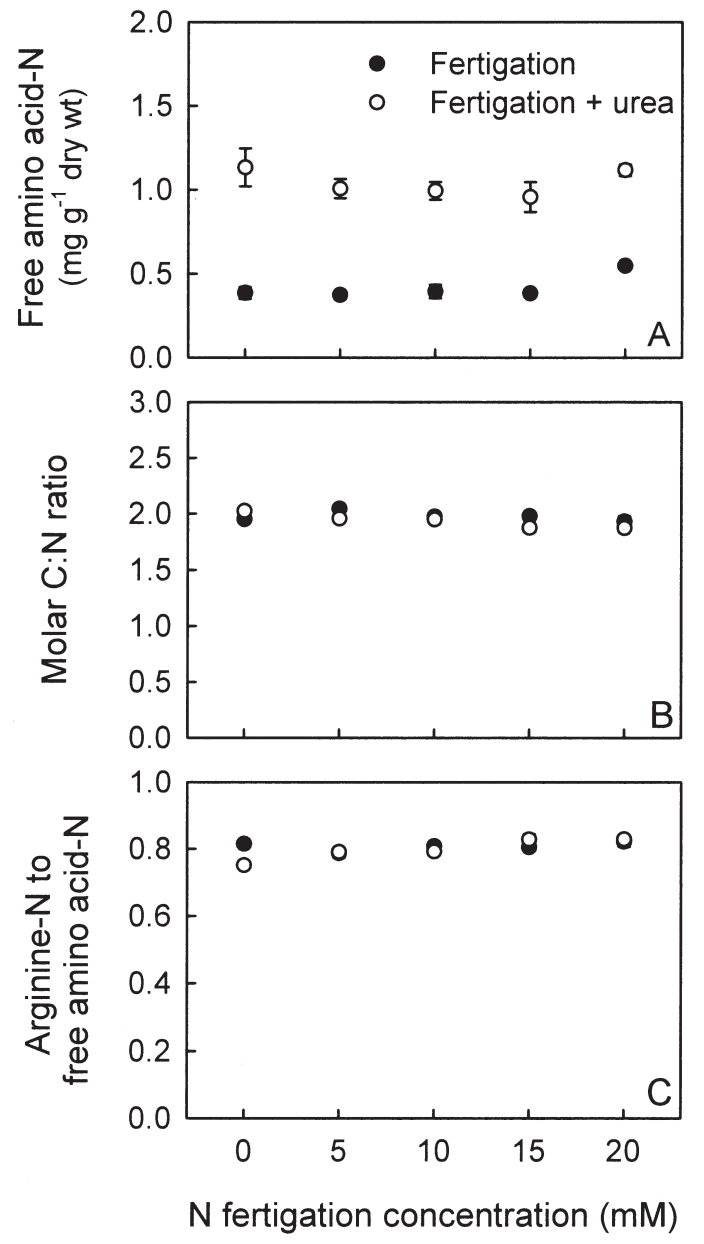

Fig. 3. Free amino acid-N (A), molar $\mathrm{C}: \mathrm{N}$ ratio of free amino acids $(\mathbf{B})$, and arginine-N to free amino acid-N of dormant 'Concord' grapevines in response to $\mathrm{N}$ fertigation during summer and foliar urea application in the fall. Vines were destructively sampled on 26 Mar. 2002 after pruning to 20 nodes per vine. Each point is a mean with standard error of four replicates. All three dependent variables were analyzed by analysis of variance for a 5 ( $\mathrm{N}$ fertigation $) \times 2$ (foliar urea) factorial experiment with a completely randomized design. In (A), $P$ value is $<0.0001$ for foliar urea with no significant effect of $\mathrm{N}$ fertigation or interaction between the two $(P>0.05)$. In both $(\mathbf{B})$ and $(\mathbf{C})$, there is no significant effect of $\mathrm{N}$ fertigation or foliar urea $(P>0.05)$.

cantly affected by $\mathrm{N}$ fertigation or foliar urea application (Fig. 7C). Starch concentration did not change significantly in response to $\mathrm{N}$ fertigation except that the vines fertigated without $\mathrm{N}$ had a higher starch concentration (Fig. 7D). Foliar urea application in the fall significantly decreased starch concentration at each $\mathrm{N}$ fertigation treatment.

TOTAL CARBON IN TNC, PROTEINS, AND FREE AMINO ACIDS. As N supplied from fertigation increased, the carbon in TNC decreased slightly, whereas the carbon in proteins and free amino acids remained unchanged except for a slight increase at the highest $\mathrm{N}$ concentration (Fig. 8 A, B). Foliar urea application in the fall decreased the carbon in TNC, but increased the carbon in proteins and free amino acids across the $\mathrm{N}$ fertigation treatments. Approximately $60 \%$ of the carbon decrease in TNC caused by foliar urea application was recovered in proteins and amino acids. The sum of carbon in proteins, free amino acids, and TNC did not change significantly in response to $\mathrm{N}$ fertigation (Fig. 8C).
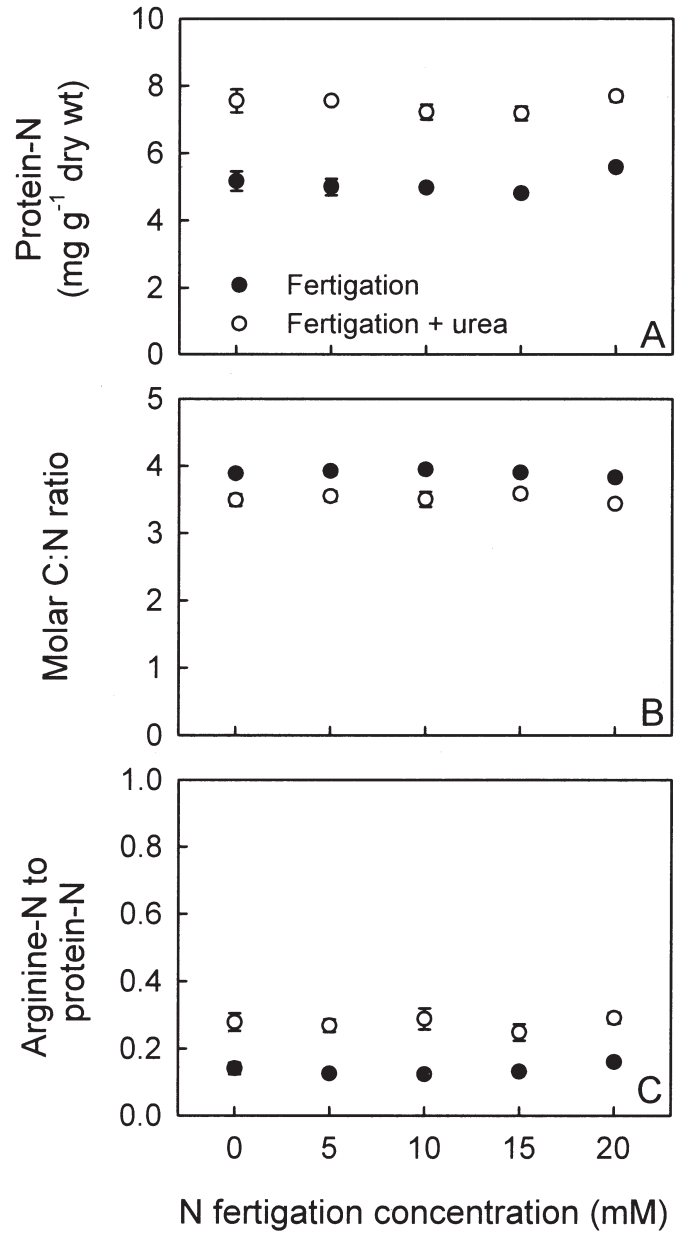

Fig. 4. Protein-N (A), molar $\mathrm{C}: \mathrm{N}$ ratio of proteins (B), and arginine-N to protein$\mathrm{N}$ (C) of dormant 'Concord' grapevines in response to $\mathrm{N}$ fertigation during summer and foliar urea application in the fall. Vines were destructively sampled on 26 Mar. 2002 after pruning to 20 nodes per vine. Each point is a mean with standard error of four replicates. Each dependent variable was analyzed by analysis of variance for a 5 ( $\mathrm{N}$ fertigation) $\times 2$ (foliar urea) factorial experiment with a completely randomized design. For all the three dependent variables, $P$ values are $<0.0001$ for foliar urea, with no significant effect of $\mathrm{N}$ fertigation or interaction between the two $(P>0.05)$.

Foliar urea application in the fall slightly decreased the sum of carbon in proteins, free amino acids, and TNC.

\section{Discussion}

Foliar urea application in the fall decreased TNC concentrations while increasing concentrations of both protein- $\mathrm{N}$ and free amino acid-N in young 'Concord' grapevines (Figs. 2, 3, 4, 5). Approximately $60 \%$ of the carbon decrease in TNC caused by foliar urea application was recovered in proteins and amino acids (Fig. 8). Therefore, foliar urea application in the fall increased both nitrogen and carbon storage in proteins and free amino acids by converting some of the carbohydrates to proteins and amino acids, but decreased carbon storage in nonstructural carbohydrates.

In response to foliar urea application, concentrations of both protein- $\mathrm{N}$ and free amino acid-N of young 'Concord' grapevines increased (Figs. 3A, 4A), but the ratio of protein-N to free amino acid-N decreased (Fig. 5C). This is similar to that found in young 

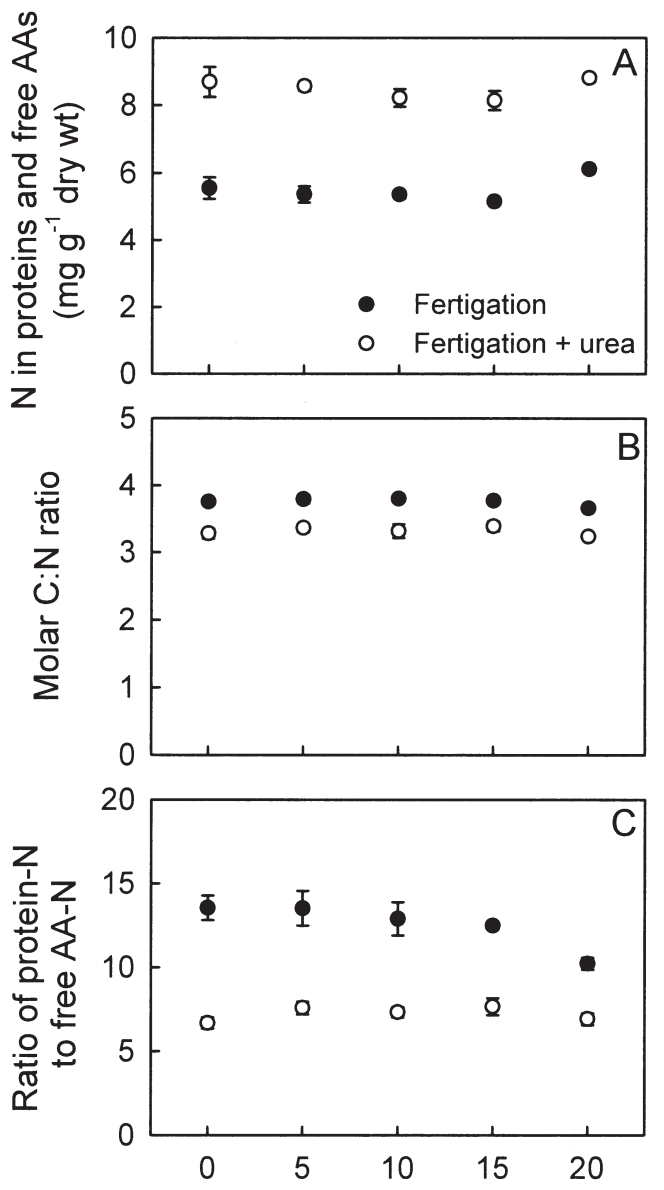

$\mathrm{N}$ fertigation concentration $(\mathrm{mM})$

Fig. 5. $\mathrm{N}$ in proteins and free amino acids (AAs) (A), molar $\mathrm{C}: \mathrm{N}$ ratio of proteins and free amino acids $(\mathbf{B})$, and protein-N to free amino acid-N (C) of dormant 'Concord' grapevines in response to $\mathrm{N}$ fertigation during summer and foliar urea application in the fall. Vines were destructively sampled on 26 Mar. 2002 after pruning to 20 nodes per vine. Each point is a mean with standard error of four replicates. All the dependent variables were analyzed by analysis of variance for a 5 ( $\mathrm{N}$ fertigation $) \times 2$ (foliar urea) factorial experiment with a completely randomized design. In both $(\mathbf{A})$ and $(\mathbf{B}), P$ values are $<0.0001$ for foliar urea, with no significant effect of $\mathrm{N}$ fertigation or interaction between the two $(P$ $>0.05)$. In $(\mathbf{C}), P$ values are $0.02,<0.0001$, and 0.04 for $\mathrm{N}$ fertigation, foliar urea, and the interaction between the two.

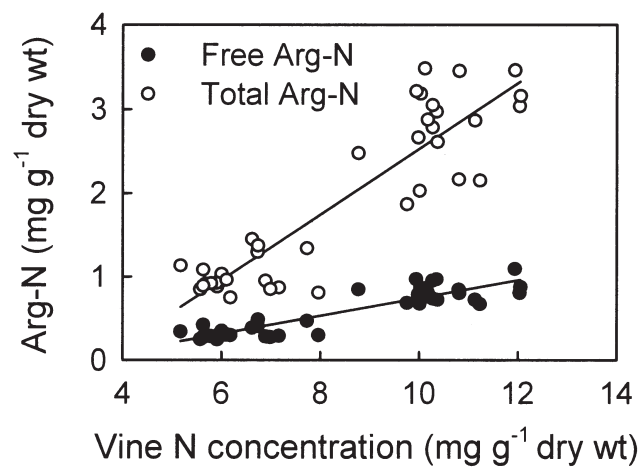

Fig. 6. Free arginine-N (Arg-N) and total Arg-N in relation to $\mathrm{N}$ concentration of dormant 'Concord' grapevines. Vines were destructively sampled on 26 Mar. 2002 after pruning to 20 nodes per vine. Regression equations: for free $\mathrm{Arg}-\mathrm{N}$, $\mathrm{Y}=-0.329+0.107 \mathrm{X}\left(r^{2}=0.814, P<0.0001\right)$; for total Arg-N, $\mathrm{Y}=-1.392+$ $0.392 \mathrm{X}\left(r^{2}=0.813, P<0.0001\right)$.
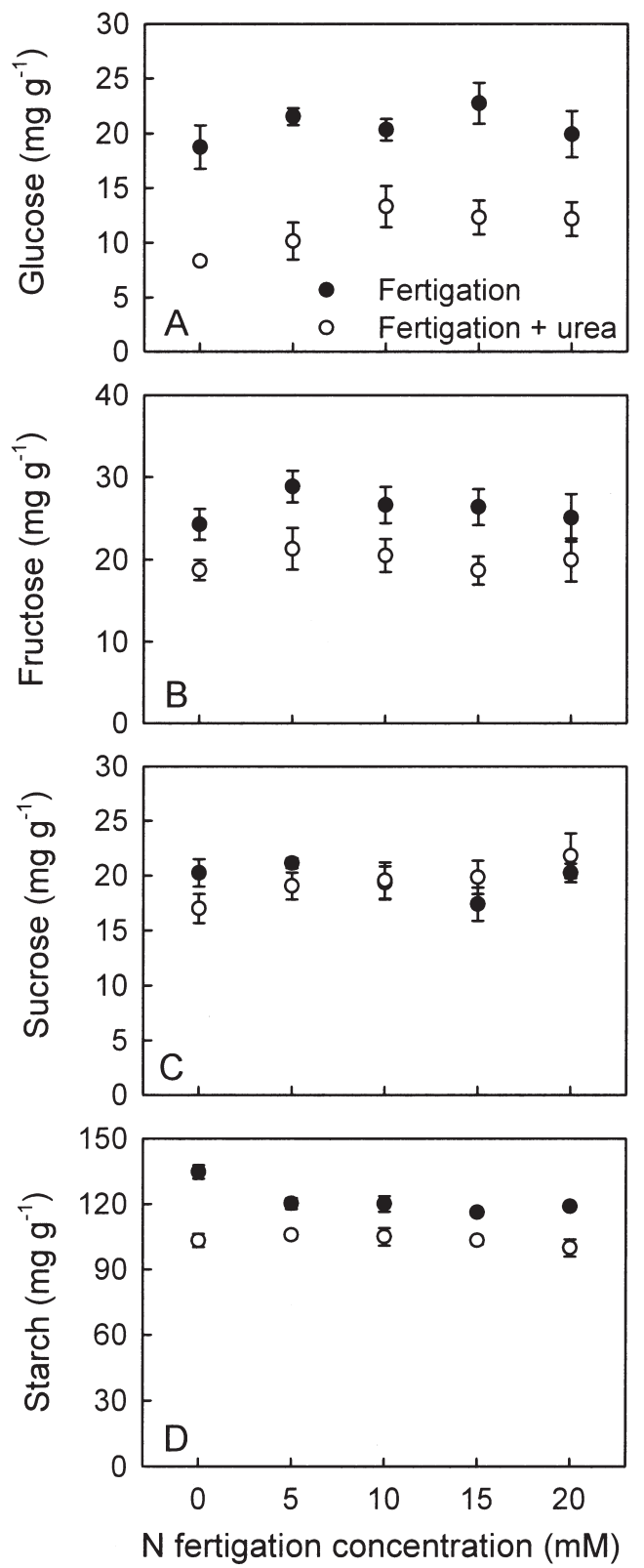

Fig. 7. Concentrations of glucose (A), fructose $(\mathbf{B})$, sucrose $(\mathbf{C})$, and starch $(\mathbf{D})$ of dormant 'Concord' grapevines in response to $\mathrm{N}$ fertigation during summer and foliar urea application in the fall. Vines were destructively sampled on $26 \mathrm{Mar}$. 2002 after pruning to 20 nodes per vine. Each point is a mean with standard error of four replicates. All the dependent variables were analyzed by analysis of variance for a 5 ( $\mathrm{N}$ fertigation) $\times 2$ (foliar urea) factorial experiment with a completely randomized design. In (A), (B) and (D), $P$ values are $<0.0001$ for foliar urea, with no significant effect of $\mathrm{N}$ fertigation or interaction between the two $(P>0.05)$. In $(\mathbf{C})$, there is no significant effect of $\mathrm{N}$ fertigation or foliar urea $(P>0.05)$.

apple trees (Cheng et al., 2004a). Compared with proteins, free amino acids have a much lower $\mathrm{C}: \mathrm{N}$ ratio due to the presence of a higher proportion of arginine (Figs. 3C, 4C). Therefore, partitioning a larger proportion of $\mathrm{N}$ into free amino acids allows more efficient use of the carbon resource. These free amino acids are readily available for the new growth in the spring (Kang et al., 1982; Kliewer, 1967). The highest proportion of free amino acid-N that arginine- $\mathrm{N}$ accounted for was approximately $80 \%$ in 

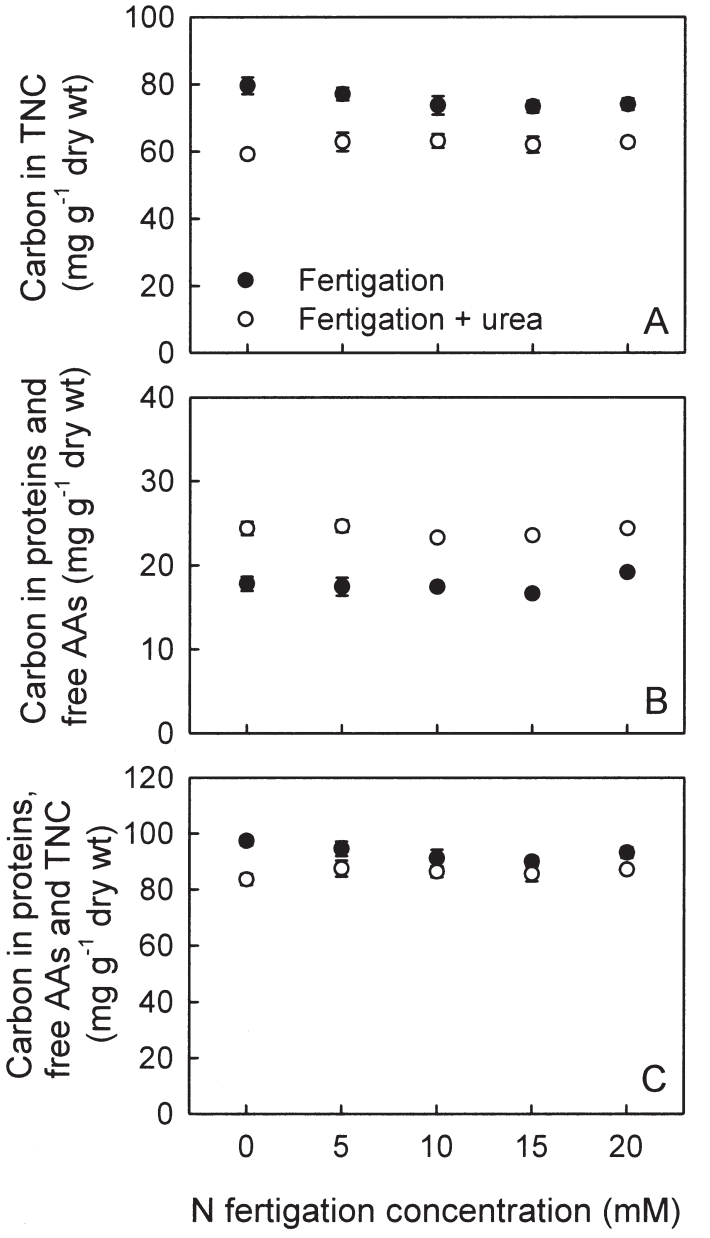

Fig. 8. Carbon in total nonstructural carbohydrates (TNC) (A), carbon in proteins and free amino acids (AAs) (B), and sum of carbon in proteins, free AAs and TNC (C) of dormant 'Concord' grapevines in response to $\mathrm{N}$ fertigation during summer and foliar urea application in the fall. Vines were destructively sampled on 26 Mar. 2002 after pruning to 20 nodes per vine. Each point is a mean with standard error of four replicates. All three dependent variables were analyzed by analysis of variance for a 5 ( $\mathrm{N}$ fertigation) $\times 2$ (foliar urea) factorial experiment with a completely randomized design. In both $(\mathbf{A})$ and (B), $P$ values are $<0.0001$ for foliar urea, with no significant effect of $\mathrm{N}$ fertigation or interaction between the two $(P>0.05)$. In $(\mathbf{C}), P$ value is 0.0004 for foliar urea with no significant effect of $\mathrm{N}$ fertigation or interaction between the two $(P>0.05)$.

both young 'Concord' grapevines (Fig. 3C) and apple trees (Cheng et al., 2004a), which led to a $\mathrm{C}: \mathrm{N}$ ratio of 2 in free amino acids. Foliar urea application did not further increase this proportion in 'Concord' vines (Fig. 3C). However, the proportion of arginine in proteins increased significantly in response to foliar urea application (Fig. 4C), making $\mathrm{N}$ storage in proteins more cost-effective (Fig. 4B). The close correlations between vine $\mathrm{N}$ concentration and free arginine-N and total arginine-N (Fig. 6) confirm previous findings that arginine- $\mathrm{N}$ is a good indicator for vine reserve N status (Kliewer, 1967; Kliewer and Cook, 1971).

Our results (Fig. 5C) clearly showed that proteins were the main form in which nitrogen was present in dormant young 'Concord' grapevines regardless of whether vines were sprayed with foliar urea or not. This is consistent with the result obtained on young apple trees (Cheng et al., 2004a). Analysis of amino acids in proteins allowed us to estimate the $\mathrm{C}: \mathrm{N}$ ratio of the proteins as a whole, but we could not determine how many proteins were present in dormant 'Concord' vines and which ones played a major role in $\mathrm{N}$ storage. The regrowth test of the vines from this experiment indicated that approximately $40 \%$ of the total vine $\mathrm{N}$ was remobilized to support the new growth (shoots, leaves, and fruit) the following season for vines that received only $\mathrm{N}$ fertigation, and $50 \%$ for those sprayed with foliar urea (Cheng et al., 2004b). Assuming that all the free amino acid-N is reserve $\mathrm{N}$ and the remobilization rates above are applicable to protein-N, the ratio of protein-N to free amino acid-N (Fig. 5C) would still indicate that proteins are the main storage form of $\mathrm{N}$ with free amino acids of secondary importance. These storage proteins are hydrolyzed in the spring to provide amino acids for the new growth. Kliewer (1967) found that concentrations of free amino acids in roots and woody tissues of 'Thompson Seedless' grapevines increased during dormancy, reached a maximum just prior to budbreak, and then decreased rapidly during the period of active vine growth. A similar pattern was also observed in apple trees (O’Kennedy et al., 1975; Oland, 1959; Tromp, 1970).

Compared with foliar urea application in the fall, increasing $\mathrm{N}$ supply from fertigation during active vine growth in summer did not significantly increase vine $\mathrm{N}$ concentration (Fig. 2A). This response is similar to that obtained with young almond trees (Bi et al., 2003) and poplar (Populus spp.) cuttings (Dong et al., 2004), but different from that of young apple trees (Cheng and Fuchigami, 2002). Apparently, young 'Concord' grapevines invest more $\mathrm{N}$ into structural growth when $\mathrm{N}$ is available during active vine growth, resulting in nearly proportional growth to $\mathrm{N}$ supply (Fig. 1A), which, in turn, keeps the vine $\mathrm{N}$ concentration largely unchanged. Only when growth slows down or stops, will $\mathrm{N}$ supply significantly increase vine $\mathrm{N}$ concentration. This may explain why foliar urea application in the fall was so effective in improving vine $\mathrm{N}$ status. Another reason that we did not see a significant increase in vine $\mathrm{N}$ concentration in response to $\mathrm{N}$ fertigation is that no additional $\mathrm{N}$ was provided to the roots of the vines during the postfertigation period. It has been demonstrated that $\mathrm{N}$ uptake during the postharvest period accounted for $27 \%$ to $34 \%$ of the total annual $\mathrm{N}$ uptake (Conradie, 1980, 1986) and provided $60 \%$ of the stored $\mathrm{N}$ for the next season for 'Chenin blanc' grapevines grown in a warm climate with a long postharvest period (Conradie, 1992). Lack of $\mathrm{N}$ supply in sand culture late in the season in our study may have prevented the vines from taking up $\mathrm{N}$ that would be primarily used for storage, although New York has a much shorter postharvest period than South Africa and the contribution of this soil-applied (derived) $\mathrm{N}$ in the fall would be expected to be smaller. Therefore, vines grown in the field may respond to soil $\mathrm{N}$ supply in a less extreme manner as we observed with nonbearing vines in sand culture.

The significant decrease in TNC in response to foliar urea application in the fall (Fig. 2B) clearly showed that assimilation of inorganic nitrogen uses carbohydrates for carbon skeleton and energy supply (Faust, 1989; Taylor et al., 1975). It is interesting to note that sucrose was the only nonstructural carbohydrate that did not decrease in response to foliar urea application in the fall (Fig. 7C). This contrasts with that found in young apple trees, where sucrose concentration was decreased by foliar urea application. Of the carbon decrease in TNC of 'Concord' vines in response to foliar urea application, approximately $40 \%$ was not recovered in proteins and free amino acids, which may have been used by other processes, including respiration. 


\section{Literature Cited}

Bates, T., R. Dunst, and P. Joy. 2002. Seasonal dry matter, starch, and nutrient distribution in 'Concord' grapevine roots. HortScience 37:313-316.

Bi, G., C.F. Scagel, L. Cheng, S. Dong, and L.H. Fuchigami. 2003. Spring growth of almond nursery trees depends upon nitrogen from both plant reserves and spring fertilizer application. J. Hort. Sci. Biotechnol. 78:853-858.

Chen, L.S. and L. Cheng. 2003. Carbon assimilation and carbohydrate metabolism of 'Concord' grape (Vitis labrusca L.) leaves in response to nitrogen supply. J. Amer. Soc. Hort. Sci. 128:754-760.

Cheng, L. and L.H. Fuchigami. 2000. Rubisco activation state decreases with increasing nitrogen content in apple leaves. J. Expt. Bot. 51:1687-1694.

Cheng, L. and L.H. Fuchigami. 2002. Growth of young apple trees in relation to reserve nitrogen and carbohydrates. Tree Physiol. 22:1297-1303.

Cheng, L., S. Dong, and L.H. Fuchigami. 2002. Urea uptake and nitrogen mobilization by apple leaves in relation to tree nitrogen status in autumn. J. Hort. Sci. Biotechnol. 77:13-18.

Cheng, L., F. Ma, and D. Ranwala. 2004a. Nitrogen storage and its interaction with carbohydrates of young apple trees in response to nitrogen supply. Tree Physiol. 24:91-98.

Cheng, L., G. Xia, and T. Bates. 2004b. Growth and fruiting of young 'Concord' vines in relation to reserve nitrogen and carbohydrates. J. Amer. Soc. Hort. Sci. 129:660-666.

Conradie, W.J. 1980. Seasonal uptake of nutrients by Chenin blanc in sand culture: I. Nitrogen. South Afr. J. Enol. Viticult. 1:59-65.

Conradie, W.J. 1986. Utilization of nitrogen by the grapevine as affected by time of application and soil type. South Afr. J. Enol. Viticult. 7:76-83.

Conradie, W.J. 1991. Translocation and storage of nitrogen by grapevines as affected by time of application, p. 32-42. In: J.M. Rantz (ed.). Proc. Intl. Symp. Nitrogen in Grapes and Wine. Amer. Soc. Enol. Viticult., Davis, Calif.

Conradie, W.J. 1992. Partitioning of nitrogen in grapevines during autumn and the utilization of nitrogen reserves during the following growing season. South Afr. J. Enol. Viticult. 13:45-51.

Dong, S., L. Cheng, C.F. Scagel, and L.H. Fuchigami. 2004. Nitrogen mobilization, nitrogen uptake and growth of cuttings obtained from poplar stock plants grown in different $\mathrm{N}$ regimes and sprayed with urea in autumn. Tree Physiol. 24:355-359.

Faust, M. 1989. Physiology of temperate zone fruit trees. Wiley Interscience, New York, 338p.

Hanson E.J. and G.S. Howell. 1995. Nitrogen accumulation and fertilizer use efficiency by grapevines in short season growing areas. HortScience 30:504-507.

Kang, S.M., K.C. Ko and J.S. Titus. 1982. Mobilization and metabolism of protein and soluble nitrogen during spring growth of apple tress. J. Amer. Soc. Hort. Sci. 107:209-213.
Kliewer, W.M. 1967. Annual cyclic changes in the concentration of free amino acids in grapevines. Amer. J. Enol. Viticult. 18:126-137.

Kliewer W.M. and J.A. Cook. 1971. Arginine and total free amino acids as indicators of the nitrogen status of grapevines. J. Amer. Soc. Hort. Sci. 96:581-587.

Löhnertz, O. 1988. Nährstoffelementaufnahme von Reben im Verlauf eines Vegetationszyklus. Mitt. Klosterneuburg 38:124-129.

Löhnertz, O. 1991. Soil nitrogen and the uptake of nitrogen in grapevines, p.1 -11. In: J.M. Rantz (ed.). Proc. Intl. Symp. Nitrogen in Grapes and Wine. Amer. Soc. Enol. Viticult., Davis, Calif.

O'Kennedy, B.T., M.J. Hennerty, and J.S. Titus. 1975. Changes in the nitrogen reserves of apple shoots during the dormant season. J. Hort. Sci. 50:321-329.

Oland, K. 1959. Nitrogenous reserves of apple tress. Physiol. Plant. 12:594-648.

Oland, K. 1963. Responses of cropping apple trees to post-harvest urea sprays. Nature 198:1282-1283.

Oliveira, C.M. and C.A. Priestley. 1988. Carbohydrate reserves in deciduous fruit trees. Hort. Rev. 10:403-430.

Rosecrance, R.C., R.S Johnson, and S.A. Weinbaum. 1998. The effect of timing of post-harvest foliar urea sprays on nitrogen absorption and partitioning in peach and nectarine trees. J. Hort. Sci. Biotechnol. 73:856-861.

Sanchez, E.E., T.L. Righetti, D. Sugar, and P.B. Lombard. 1990. Response of 'Comice' pear trees to a postharvest urea spray. J. Hort. Sci. 65:541-546.

Schaller, K., O. Löhnertz, R. Geiben, and N. Breit. 1989. N-Stoffwechsel von Reben: N- und Arginindynamik im Holzkörper der Sorte Müller-Thurgau im Verlaufe einer Vegetationsperiode. Wen-Wiss, 44:91-101.

Shim, K.K., J.S. Titus, and W.E. Splittstoesser. 1972. The utilization of post-harvest urea sprays by senescing apple leaves. J. Amer. Soc. Hort. Sci. 97:592-596.

Tagliavini, M., P. Millard, and M. Quartieri. 1998. Storage of foliar-absorbed nitrogen and remobilization for spring growth in young nectarine (Prunus persica var. nectarina) trees. Tree Physiol. 18:203-207.

Taylor, B.K., B. van den Ende, and R.L. Canterford. 1975. Effects of rate and timing of nitrogen applications on the performance and chemical composition of young pear trees, cv. Williams' Bon Chretien. J. Hort. Sci. 50:29-40.

Tromp, J. 1970. Storage and mobilization of nitrogenous compounds in apple trees with special reference to arginine, p. 145-159. In L.C. Luckwill and C.V. Cutting (eds.). Physiology of tree crops. Acad. Press, N.Y.

Wermelinger, B. 1991. Nitrogen dynamics in grapevine: physiology and modeling, p. 23-31. In: J.M. Rantz (ed.). Proc. Intl. Symp. Nitrogen in Grapes and Wine. Amer. Soc. Enol. Viticult., Davis, Calif.

Williams, L.E. 1991. Vine nitrogen requirements-Utilization of $\mathrm{N}$ sources from soils, fertilizers, and reserves, p. 62-66. In: J.M. Rantz (ed.). Proc. Intl. Symp. Nitrogen in Grapes and Wine. Amer. Soc. Enol. Viticult., Davis, Calif. 